\title{
Road Haulage Constraints in the Transportation of Petroleum Products in Northern Nigeria
}

\author{
Thompson O. Obasanjo; Martina Francis; James J. Williams \\ Department of Geography, Adamawa State University, Mubi, Adamawa State, Nigeria \\ Department of Geography, Adamawa State University, Mubi, Adamawa State, Nigeria \\ Department of Geography, College of Education Hong, Adamawa State, Nigeria.
}

\begin{abstract}
In Nigeria, about $80 \%$ of petroleum movements are done on the road and there has been a steady growth in number of road tanker vehicles. This study examines road haulage constraints in the transportation of petroleum products. The study relied on primary data obtained through systematic administration of questionnaire to truck drivers at the point of waiting to load petroleum products in Kaduna Refinery. In all, 182 respondents were sampled. These problems were rank-ordered, the result of the study reveals that the major constraint confronting tanker drivers in conveying petroleum products to the selected locations is delay at police and military check points (mean $=1.72$ ), followed by mechanical problems (mean $=2.17$ ), using $K$-W non parametric test. Furthermore, the correlation matrix of the trucking problem result reveals that five pairs of the constraints were significant with the strongest positive correlation being that of bad roads and delay in offloading, $r=0.81, p<0.001$. These results are fundamental for the prioritization of palliative measures to improve the constraints of road haulage of petroleum products in northern Nigeria.
\end{abstract}

Keywords: Road, haulage, constraints, transportation, petroleum products.

\section{Introduction}

Transportation is an important aspect in the distribution of petroleum products as the production centers are usually far from consuming areas. A large proportion of the world's refineries are located far from the market. The fluidity of most of the petroleum products makes it amendable to transportation by any agency capable of removing a liquid from one place to another by trucks, railroads, ships and pipeline (Ikporukpo, 1977).

Petroleum is the most significant mineral resource in Nigeria. It accounts for over 95 percent of export earnings and about 85 percent of government revenues than any other mineral or product and the country's oil reserves as at 2010 is 31 billion barrels (Economic Confidence, 2012), while gas reserves were 159.08 trillion standard cubic feet (OPEC, 2003). The country produced 1.8million Barrels per day of crude oil in 2002 and of this (99.8 percent) was exported (OPEC, 2006). Before 1986, hardly any petroleum product was imported as the local refineries were functioning properly and were regularly maintained. However, from 1990, the percentage share of imported petroleum products began to rise. The importation of Premium Motor Spirit and Dual Purpose Kerosene rose from 11.4 percent and 13.30 percent respectively, especially in 1990 to 82 percent and 64.87 percent respectively 2000. According to Nigerian National Petroleum Corporation (NNPC), the refineries could produce 18 million litres of PMS per day at full capacity, while consumption is 30 million litres (TELL Nigeria, 2005). Consequently the balance of 12 million has to be imported (OPEC, 2006).

In Nigeria, refined petroleum products are supposed to be transported from the three refineries in Kaduna, Portharcourt and Warri through a network of pipelines, coastal (marine) vessels, road trucks and rail wagons to the 21 regional storage/distribution depots, spread across the country. It is from these depots that the marketing companies are supposed to obtain their supplies. These distribution depots, with a total capacity of 1,422,000 cubic metres, and the pipeline transportation system are managed by NNPC through its subsidiary, the Pipelines and Products Marketing Company (PPMC). The depots are linked to the refineries and port terminals by a $3,949 \mathrm{~km}$ network of pipelines for the transportation of refined products in five systems (Mbendi, 2011). About $80 \%$ of petroleum movements are done on the road and there has been a steady growth in number of road tanker vehicles. There is an estimate of 5,000 tankers involved in wet cargo haulage, to move about 150 million litres of fuel and 2,500 trailers in dry cargoes plying Nigeria roads daily. However, bad roads, poor road networks and also various hindrances such as delays at police and customs check points obstructs an effective and efficient logistics (Olagunju, 2011).

Studies of the operation constraints of long haul trucking are usually done in conjunction with driver behaviour (Golob and Hensher, 1997; Hensher et al., 1993), accidents (Loeb and Clark, 2007), disruptions in supply chain (Wilson, 2007; Hendricks and Singhal, 2005), cost of operations (World Bank, 2007) and short deliveries of petroleum products (Abdulmalik and Omokoghio, 2009). The general approach of the behavioural theme has been to relate the operational problems of trucking to the behavioural pattern of long distance drivers. 
It is argued, for instance, that trucker by their nature indulge in long distance driving and so experience sleepless nights that are fundamental for the explanations of risks and subsequent accidents (Savage, 1989). This position has, however, not gone unchallenged. Loeb and Clark (2007) commenting on accidents of truck drivers have very well acknowledged that, indeed, the miles driven on roadways, alcohol consumption by truck drivers, and age of truck drivers have been shown to be positively linked to accidents.

Study by FHWA (2009) has shown that highway bottlenecks' arising from delays is estimated to be caused by non-recurring congestion. The result of transitory events such as construction work zones, crashes, breakdowns, extreme weather conditions and suboptimal traffic controls are all cases of delays in freight transport delivery. Consequently, the report notes with dismay that truck delay bottlenecks increases costs to business and consumers. To other writers, their approach has been to examine the trucking operational problems within the framework of supply chain, since transport performs a critical role by enabling products to be made available at locations desired by the consumers (Potter and Lalwani, 2008) and that any disruption to material flows in the supply chain results in an abrupt cessation of the movement of goods (Wilson, 2007). According to Chopra and Sodhi (2004) transportation disruptions can occur as a result of natural disasters, labour disputes, terrorist activities and infrastructure failures. These disruptions have the propensity to stop the flow of goods when such goods in transit are interrupted. Imperatively, a disruption in transportation will certainly delay the arrival of consignments at destination points.

However, several studies in Nigeria (Oni, 2000; Oni and Okanlawon, 2006; Ubogu 2005; World bank, 2007; Ubogu et al 2011) suggest that poor roads, narrow bridges, menace of armed robbery on highways, harassment by security officials, touting, delays occasioned by traffic congestion, outright non-delivery of consignments consequent upon accidents, shortage or scarcity of fuel, incessant vehicle breakdown and traffic hold-up in the city centers are some of the operational difficulties confronting goods haulage in the country. Quite often, commentators have identified poor quality of roads as a major drawback for transportation of consignments, in spite of the fact that, road haulage has been and still remains the most favoured mode for the movement of petroleum products (Oni, 2008).

One major aspect that has been missing from various studies in Nigeria has been the order and extent of the constraints. Infact, the constraints on transportation of petroleum products by road have received only limited coverage in the oft cited works on long haul. Previous studies on transportation of petroleum products have not sought to explicitly quantify the order and extent of the constraints, though the nature of the clogs in long haul transportation of petroleum products have been implied.

The fact that most of the analyses of the different studies were undertaken in countries where road haulage industry is under varying levels of regulation suggests that the identified problems might not yield identical results. This is because the economic regulation of rates, entry and standard of practice influences the operating practices of the industry (Harper and Johnson, 1987).

The fundamental objective of this paper is to provide an insight into the order and extent of constraints associated with transportation of petroleum products by road in northern Nigeria. Applying rank-ordered technique, this study determines the order of constraints facing the smooth operations of petroleum products delivery from the refinery to the destination.

\section{The data and analytical technique}

\section{Methodology}

The primary source of data was from a structured questionnaire administered to tanker drivers. A sample comprising of 182 tanker drivers sampled in Kaduna Refinery and Petro-chemical Company (KRPC) were selected. The tanker drivers were sampled systematically by asking every seventh tanker driver at the point of loading or waiting at the refinery. The questionnaire was used to elicit information on the characteristics of the tanker drivers as well as the problems encountered in transporting petroleum products to northern Nigeria. Apart from descriptive statistics, the Kruskal-Wallis method of non-parametric test for repeated measure analysis was used to evaluate the extent and rank-order of the constraints. This method is used to determine the rank-order of the constraints associated with road haulage in conveying petroleum products to northern Nigeria. Its analytical function is to compare the mean ranks for the rank-order problems. The K-W test is often used to detect the overall difference in distribution among the groups under consideration. The technique is ideal for analyzing data of this nature (Ugwuegbu, 2004; Morgan et al, 2004; Ubogu et al, 2011). Also the Spearman's correlation matrix was used to investigate the nature of the association between the pairs of the constraints.

\section{The study area}

Roads provide by far the most important mode of transport in Nigeria. The highways in the country generally account for about 70\% of the movement of goods and persons in the country (Akpogomeh, 2002). This is largely attributed to the natural advantage provided by the existence of vast land mass in northern 
Nigeria, when compared with waterways, and perhaps the inadequate attention being given to other modes of transportation (Adesanya, 1998). The major cities, include the 19 states capitals and the federal capital are connected to each other by a network of two-lane highways; with some main connections being four-lane, dual carriageway type. Generally, the roads are classified into trunk A, B, and C roads constructed, managed and owned by the three tiers of government. Essentially, trunk A roads are the responsibility of the federal government (Digest of Transport Statistics, 2004) the majority of which are the paved highways of northern Nigeria. Presently, some of the roads are in deplorable condition in most parts of northern Nigeria (Oni and Okanlawon, 2006).

The Nigerian road haulage industry has developed tremendously over the past $15-20$ years. This is the growing reliance on road transportation and the relegation of other modes in long haul freight transport. Incidentally, there are no reliable statistics on the total tanker market in northern Nigeria but it is estimated that the northern Nigeria tanker's market is about 5,000 - 10,000 units annually (Olagunju, 2011).

\section{Results and discussion}

\section{Socio-economic characteristics and areal coverage of the tanker drivers}

In analyzing and evaluating any freight constraints of goods haulage, there is the need to consider the socio-economic characteristics of the respondents as indicated in the survey. The information is fundamental to this study as it facilitates the understanding of more complex analysis of data obtained from the sampled respondents. The age of tanker driver has significant implication on the performance and behaviour of tanker driver on the road. The age categorization was based on the fact that the minimum driving age in Nigeria is 18 years. In other words, the categorization is a reflection of economically productive segment of the population. Age distribution as shown in Figure 1 reveals that, the age group of $33-37$ years has the highest proportion of respondent which represents 26.9 percent, followed by 23.6 percent for the age of $38-42$ years while $18-22$ years accounts for the least representing 0.5 percent. In general, the result indicates that the predominant age group of the petroleum tanker drivers surveyed falls between the ages of $28-52$ years which lies among the independent age. Overall, this age range accounts for 96.6 percent.

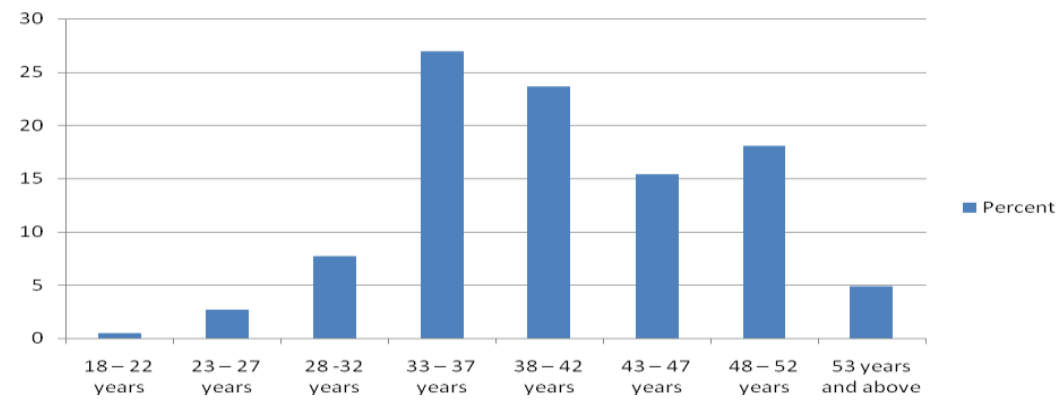

Figure 1: Percentage distribution by age of the tanker drivers

The age of the tanker drivers has many significant implications for the performance potentials of the transport industry and most active group in the transport industry. The biological age and length of service has close relationship with professional competence, efficiency and risk indicators of petroleum product tanker driving (Bashkireva and Khavinson, 2001). The age structure of the sample tanker drivers shows a characteristic " $n$ " distribution pattern. This result is similar to findings of Ubogu et. al. (2011). From this result, it is apparent that the extremely active age group is involved in tanker driving. According to Fergusen (2003), teenage drivers are inexperienced with immature judgment and have the desire to take risks. One of the reasons made known by the tanker drivers for the age group was the years it takes to learn tanker driving and the tedious nature, which also has gendered implications.

The length of driving also has great impact on the driver's performance, professional competence, risk indicators and obedience to rules and regulations on roads. The distribution by length of driving, like that of age, is an important performance parameter. Table 1 shows the respondents' length of driving. 
Table 1: Length of Driving for the organization

\begin{tabular}{ccc}
\hline Length of Driving & Number & Percentage \\
\hline $1-5$ years & 82 & 45.1 \\
$6-10$ years & 76 & 41.8 \\
$11-15$ years & 16 & 8.8 \\
$16-20$ years & 6 & 3.3 \\
$26-30$ years & 1 & 0.5 \\
No response & 1 & 0.5 \\
\hline Total & $\mathbf{1 8 2}$ & $\mathbf{1 0 0 . 0}$ \\
\hline
\end{tabular}

Table 1 shows that 45.1 percent have been driving for $1-5$ years, 41.8 percent have also been driving for $6-10$ years, and 0.5 percent has been driving for $26-30$ years. This result indicates that most of the tanker drivers have been driving for not less than a year.

Table 2: Cross tabulation of age and length of driving of tanker drivers

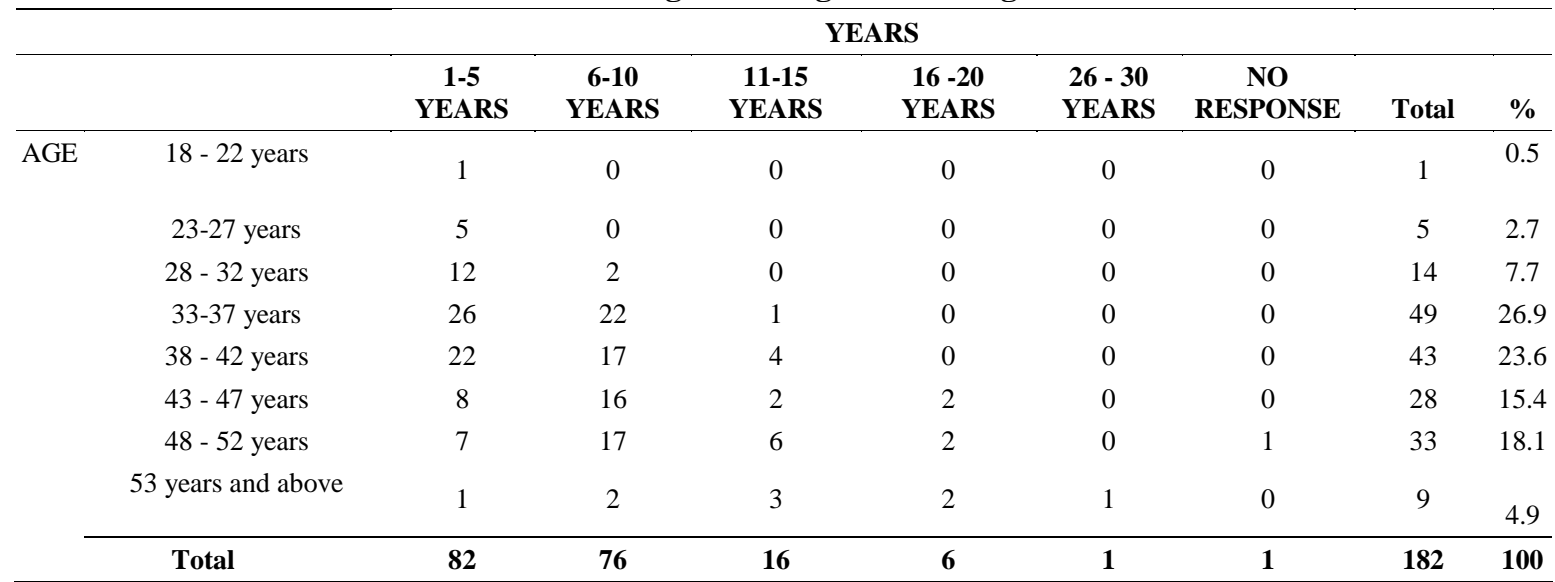

Table 2 reveals the cross tabulation of the age of drivers and the length of driving, it is apparent that as the age of the respondent increases, the length of driving decreases, which indicates that age of the driver affects the years of driving due to the tedious nature of tanker driving.

The educational level of the tanker driver has implications for the use of road as it helps drivers to understand the various road signs, traffic rules and regulations necessary for effective operations while driving on the roads. Table 3 shows the educational status of the respondents.

Table 3:Educational Status of the tanker drivers

\begin{tabular}{ccc}
\hline Educational Status & Number & Percentage \\
\hline Non formal education & 37 & 20.3 \\
Primary education & 63 & 34.6 \\
Secondary education & 70 & 38.5 \\
Tertiary education & 7 & 3.8 \\
No response & 5 & 2.7 \\
\hline Total & $\mathbf{1 8 2}$ & $\mathbf{1 0 0 . 0}$ \\
\hline
\end{tabular}

Source: Field Survey, 2012.

The educational status as shown in Table 3 reveals that 38.5 percent has secondary education, 34.6 percent has primary education while 3.8 percent has tertiary education. From the result, it can be seen that the petroleum tanker drivers has either formal or informal education but the level of their education greatly influence their attitude and skills behind the steering when driving.

\section{The constraints of road haulage of petroleum products}

The first major problem a researcher encounters in the study of tanker operators constraints is to find out a way to measure operational problems. The approach this study adopted is quite simple, Geographic, and indeed, transport studies maintain that if you wish to know how an organization feels, you should ask the organization. The methodological technique adopted here is to present the list of a set of operational problems to the tanker drivers, who were asked to rank-order them according to the problems they encounter while transporting the petroleum products in the order of 1 to 7 . The most challenging is ranked 1 while the least challenging is ranked 7. These problems include bad roads, theft/robbery, accident, traffic congestion, mechanical problem, delay at police and military check points, short delivery due to evaporation, inter-state revenue task personnel, delay in salary and off-loading. 
The rank - order of the problems is displayed in Table 4 using Kruskal-Wallis non -parametric test for repeated measure analysis. Out of the 10 constraints listed for the respondents to rank, only four operational problems as shown in Table 4 was ranked 1. As shown in the table, the trucking constraints rank-order 1 reveals that delay at police and military check point emerged the most problematic constraint with a mean of 1.72 and a standard deviation of 0.843 . This was followed by mechanical problem developed by the tanker on the road with a mean of 2.17 and a standard deviation of 1.082. Bad roads followed mechanical problem with a mean of 2.58 and standard deviation of 1.297, traffic congestion was also ranked 1 with a mean of 3.79 and standard deviation 1.502. Of all the respondents who ranked the listed problems as the extremely challenging, 45.1 percent of the respondents ranked delay at police and military check points as the first, which was followed by mechanical problem (36.3 percent), bad roads (14.8 percent) and traffic congestion (3.8 percent).

Table 4: Rank-order of operational problems encountered by the tanker drivers

\begin{tabular}{cccccccc}
\hline Rank & Operational problems & N & Mean & $\begin{array}{c}\text { Standard } \\
\text { deviation }\end{array}$ & Variance & Number & Percent \\
\hline 1 & Delay at Police and military check & 182 & 1.72 & 0.843 & 0.711 & 82 & 45.1 \\
points & & & & & & \\
2 & $\quad \begin{array}{c}\text { Mechanical problem } \\
\text { Bad roads }\end{array}$ & 182 & 2.17 & 1.082 & 1.170 & 66 & 36.3 \\
3 & 182 & 2.58 & 1.297 & 1.681 & 27 & 14.8 \\
4 & Traffic congestion & 182 & 3.79 & 1.502 & 2.255 & 7 & 3.8 \\
\hline & Total & & & & & $\mathbf{1 8 2}$ & $\mathbf{1 0 0}$ \\
\hline
\end{tabular}

Delay at police and military check points, mechanical problem and bad roads were ranked first 3 problems because of the state of insecurity in Northern Nigeria that have led to road check point at several points, the nature of trucks, mechanical parts of the trucks and tyres purchased for replacement are usually fairly used which leads to impromptu breakdown of trucks. Due to the expensive nature of trucks and tyres, truck owners settle for fairly used trucks and their parts which have effect on the road. Poor maintenance and exerted pressure because of increase in vehicular population on the road worn out the capability of the road and it is left in a depilating state which affect the effective distribution process. The recurrent complaints of delays have sometimes been ascribed to the poor nature of roads in the country. The trucking industry in Nigeria has had to contend with poor maintenance of the roads which leads not only to high rates of accidents and cost of vehicle maintenance but also reducing the travel speed of trucks (Kanawa, 2007).

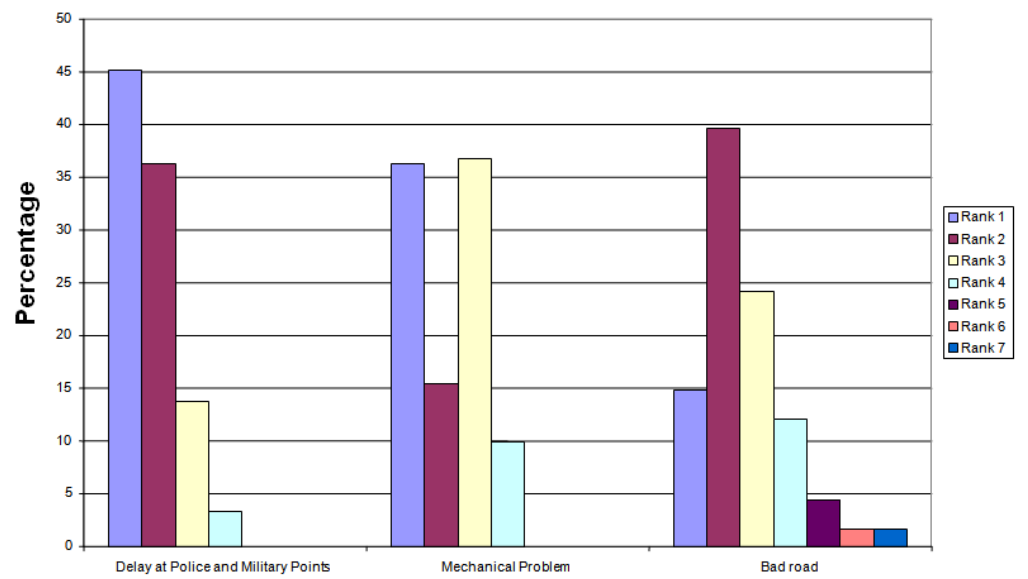

Figure 2: Percentage distributions by delay at police and military points, mechanical problem and bad road.

Further evaluation of the three problems that were ranked most in order of most challenging showed that more respondents ranked them first in importance than in other categories. For example, 45.1 percent of the respondents listed delay at police and military check points as the first major problem. Again, 36.3 percent ranked it second, 13.7 percent ranked it third, 3.3 percent ranked it fourth, fifth, sixth and seventh position did not rank it at all (see figure 2). Indeed, delay at police and military check points is the only problem where 45.1 percent of those who identified it ranked it as the most challenging. This observed degree is not surprising as Northern Nigeria is facing consistent predicament in the past few years. This result is similar to the findings of Ubogu et al (2011) that 42.1 percent identified bad roads as the major cause of increased turn-around of trucks and 40.1 percent of the respondents listed harassment from law enforcement agencies as the first major problem.

Mechanical problem was listed the second most important problem by the respondents. Out of the 182 tanker drivers interviewed, 36.3 percent ranked it first, 15.4 percent ranked it second, 36.8 percent ranked it third and 9.9 percent ranked it fourth. Figure 4.2 also shows the percentage distribution by rank-order of bad 
road as problem of transporting petroleum product by road. Bad road was listed the third most challenging problem with 14.8 percent ranking it first, 39.6 percent ranked it second with the remaining third to seventh accounting for 24.2 percent, 12.1 percent, 4.4 percent, 1.6 percent and 1.6 percent respectively. This signifies that the state of roads in northern Nigeria can affect smooth distribution of the product and turn-around time.

This study further examined the extent of the association between the problems under investigation. Table 5 shows the spearman's correlation matrix for the ten problems tagged $\mathrm{X}_{1}$ (Bad roads), $\mathrm{X}_{2}$ (Theft/Robbery), $X_{3}$ (Accident), $X_{4}$ (Traffic congestion), $X_{5}$ (Mechanical problem), $X_{6}$ (Delay at police and military check points), $X_{7}$ (Short delivery), $X_{8}$ (Inter-state revenue personnel), $X_{9}$ (Delay in salary) and $X_{10}$ (Delay in off-loading). It is obvious from the correlation matrix that 5 pairs of the variable were related. Table 5 shows the correlation matrix of association of the problems of moving petroleum products by road transportation.

Table 5: Correlation matrix of association of the problems of moving petroleum product by road transportation

\begin{tabular}{|c|c|c|c|c|c|c|c|c|c|c|}
\hline & $\mathrm{X}_{1}$ & $\mathrm{X}_{2}$ & $\mathrm{X}_{3}$ & $\mathrm{X}_{4}$ & $\mathrm{X}_{5}$ & $\mathrm{X}_{6}$ & $\mathrm{X}_{7}$ & $\mathrm{X}_{8}$ & $\mathrm{X}_{9}$ & $\mathrm{X}_{10}$ \\
\hline $\mathrm{X}_{1}$ & 1.000 & -0.207 & -0.154 & -0.209 & -0.408 & 0.087 & -0.192 & 0.080 & 0.297 & 0.81 \\
\hline$X_{2}$ & & 1.000 & 0.238 & 0.144 & -0.016 & 0.334 & -0.204 & -0.064 & -0.334 & -0.478 \\
\hline$X_{3}$ & & & 1.000 & -0.008 & 0.160 & 0.005 & 0.059 & -0.104 & -0.137 & -0.375 \\
\hline $\mathrm{X}_{4}$ & & & & 1.000 & -0.15 & -0.66 & 0.132 & -0.084 & -0.336 & -0.025 \\
\hline $\mathrm{X}_{5}$ & & & & & 1.000 & -0.449 & 0.314 & 0.055 & -0.119 & -0.064 \\
\hline $\mathrm{X}_{6}$ & & & & & & 1.000 & 0.46 & -0.176 & -0.147 & 0.019 \\
\hline $\mathrm{X}_{7}$ & & & & & & & 1.000 & -0.482 & -0.177 & 0.027 \\
\hline $\mathrm{X}_{8}$ & & & & & & & & 1.000 & 0.006 & -0.56 \\
\hline $\mathrm{X}_{9}$ & & & & & & & & & 1.000 & -0.103 \\
\hline $\mathrm{X}_{10}$ & & & & & & & & & & 1.000 \\
\hline
\end{tabular}

From the Table 5, pair $\mathrm{X}_{10}$ by $\mathrm{X}_{1}$ reveals that the higher the bad roads the higher the delay in offloading because bad roads will affect the tankers' speed, thereby increasing the number of days taken for delivery of petroleum products and off-loading. Similarly, $\mathrm{X}_{7}$ by $\mathrm{X}_{6}$ indicates that the higher the delay at police and military check points, the higher the short-delivery because petroleum products evaporates and the higher the delay, the higher the rate of evaporation and manipulation by truck drivers that eventually leads to shortdelivery. Furthermore, $\mathrm{X}_{6}$ by $\mathrm{X}_{2}$ shows that delay at police and military check points exposes the truck drivers to theft/robbery attack because the longer the tanker drivers are delayed, the longer time spent to their destination which can endanger them to theft/robbery at night. Pair $\mathrm{X}_{7}$ by $\mathrm{X}_{5}$ indicates that the higher the mechanical problem, the higher the short delivery because the tanker drivers will have to spend more days that was unplanned for and incur more expenses that can make them drain petroleum products from the tank to resale to black-marketers in order to get money to solve their mechanical problem and welfare leading to short delivery at the final destination (Petrol filling station). The correlation matrix provides a useful relationship between the problems.

Consequently upon the operational constraints of product haul in northern Nigeria, transportation experts and policy makers have often made certain allusions to the remote and immediate causes of tankers bottlenecks. Indeed, one major concern that is frequently highlighted is the proliferation of legal and illegal check points. In the words of Kanawa (2007), road blocks and artificial bottlenecks on Nigerian highways results in extortion, delays, loss of man hours and general frustration. The delays in transit occasioned by frequent harassment from police, army and other road blocks are critical instances where illegal un-receipted payments are made (Ubogu et al, 2011). This adds up to the ever increasing delivery costs of products to destined locations.

\section{Policy implications}

Although government over the years has shown considerable effort in the smooth flow of petroleum products from refineries to the final consumers, there is need to put in place practical efforts at resolving the state of insecurity on roads and issues of delays occasioned at police and military check points. Although the intent of legal check points is meaniful and worthwhile, these check points constitute a serious constraint in the free flow of petroleum products by road in Nigeria. Reducing the interference on petroleum products movement would result in significant cost reductions and minimization of delays that invariably result in additional costs that are borne by the final consumers (Mamman, 2005; Oni, 2008). In addition, with the degree of the 
constraints now identified, there is need to prioritize the analgesic often put in place by successive governments of the country to reduce and if possible eliminate these distribution difficulties.

The present condition of road transport constraints can be traced to certain remote causes that had helped to hinder the development of a reliable transport system. According to Ikporukpo and Filani (2000) the history of Nigeria's transport system was marked by an attempt at coordination. However, such attempts were virtually abandoned in later years. One vital development policy that would have helped to reduce most of the tanker's constraints has actually been a major part of the crises. As part of the attempts to ensure smooth delivery of petroleum products, to the final consumers on time and at a cheapest cost, the government should establish several depots to the available 21 depots and more rail terminals closer to the petrol filling stations. The effective functioning of petroleum depots and rail terminals would reduce to a reasonable level some of the constraints associated with transportation of petroleum products to their destination while much more time and money will be saved. Furthermore, the government should enact an educational policy to cover the standard of education an individual must attain before he/she is allowed to engage in tank driving activity and reduce the rate of tankers on the road.

Finally, efforts should be geared towards integrating the various modes of transport in the country. The policy implications arising from the findings of this study show that eliminating the hindrances will ensure free movement of petroleum products such as reducing the check points and ensure a peaceful environment for hitch-free distribution. Further research can be carried out on areas such as, the comparative analysis of mode of transporting petroleum products from the three remaining refineries, a study on the level of education and tanker drivers' performance on road in transporting petroleum products.

\section{Conclusion}

This study has identified the constraints associated with road haulage of petroleum products. The major findings of this study shows that the road mode is faced with several challenges in moving petroleum products such as bad roads, theft/robbery, accident, traffic congestion, mechanical problem, delay at police and customs check points, short delivery due to evaporation, diversion of product, inter-state revenue task personnel, delay in salary, delay in off-loading and old stock of tankers in use. Risk caused by the tank trucks on the roads mostly depends on the general transport intensity of the road section, accident rate of road section and number of tank trucks. Routes by tanks trucks in Nigeria are not regulated, therefore, risk of some routes due to tank truck accidents is larger than the pipeline. Control of tank trucks' routes enables to significantly reduce the total risk of petrol transportation. Optimizing tank trucks; routes according their length and risk indexes, risk will reduce compared to the existing situation. For further reduction of tank trucks risk, they have to be provided with portable monitoring system such as installation of GPS in the tankers, which in the case of accident or danger due to impermissible changes of controlled parameters, would send an adequate signal according to which an optimal solution would be achieved.

With increasing constraints associated with road haulage of petroleum products, there is need to regulate tanker operators to concentrate on more attractive short haul operations where road has comparative advantage. However, there is need for government to put in place measures that will substantially reduce the insecurity situation in the country. Furthermore, there is need for urgent reformation and re-habilitation of other mode of transportation such as pipeline and rail to reduce the constraints associated with road mode.

\section{References}

[1]. Abdulmalik A. and Omokoghio M. (2009), "Short Delivery of Petroleum Products at Retail locations in Kaduna Region”, Journal of Logistics and Transport, Vol. 1, No.2, 2009, pp $108-119$.

[2]. Adesanya, A. (1998) "Transport Development", in Phillips A.O and Titiola, S.T (eds) Nigeria in 2010, Nigeria Institute of Social and Economic Research (NISER) Ibadan pp. $181-193$.

[3]. Akpoghomeh, O. S (2002) "Transport and Communication" in Africa Atlas of Nigeria.Les Editions J.A., 57 bis. Rue d'Autenil. 750 16 Paris - France. pp $106-109$.

[4]. Alatarighabofa, E. (2010) "The impact of production scheduling on the distribution performance of petroleum products by KRPC" unpublished Master in Transport and Logistics, NITT, Zaria.

[5]. Bashkireva, A.S., and Khavinson, V.K., (2001), "Influence of biological age on professional efficiency: communication 1. Biological age and mental efficiency. Human Physiology 27 (3), $353-359$.

[6]. Chopra, S.C. and Sodhi, M.S. (2004), Managing risk to avoid supply-chain breakdown, MIT Sloan Management Review 1 (31), 124 -139 .

[7]. Digest of Transport Statistics, 2004, 2004 edition, No. 10.

[8]. Economic Confidence (2012), "Nigeria's oil reserve to dry in 2040", (http://economicconfidence.net/news/news/national-news/isseconomic-confidential).

[9]. Fergusen, S.A. (2003), Other high risk factors for young drivers - how graduated licensing occurrence in Nigeria : 1970 - 1995. Journal of Safety Research, Vol 34 (1) 71 - 77.

[10]. Federal Highway Administration (FHWA), (2009), An Initial Assessment of Freight Bottlenecks on Highways-Executive Summary. United States Department of Transportation (downloaded21.05.2009).http://www.fhwa.dot.gov/policy/otps/bottlenecks/execsum.htm 
[11]. Golob, T.F and Hensher, D.A (1997), Driver behaviour of long distance truck drivers: the effects of schedule compliance on drug use and speeding citations. International journal of Transport Economics 23, 267-301.

[12]. Harper, D.V. and Johnson, J.C. (1987), The potential consequences of deregulation of transportation revisited. Land Economics 63 (2), $137-146$.

[13]. Hendricks, K.B. and Singhal, V.R. (2005), An empirical analysis of the effect of supply chain disruptions on log-run stock price and equity risk of the firm. Productions and Operations Management 1 (14), 35 - 52. Working Paper ITS-WP, 93-98.

[14]. Hensher, D.A., Battelino, H.C and Daniels, R. (1993), Economic reward and on-road performance of long distance trucking: an econometric assessment. ITS

[15]. Ikporukpo, C. O. (1977), "Spatial structure and efficiency in physical distribution system: a case study of the Nigerian Gasoline Industry", Unpublished Ph.D Thesis; University of Ibadan, Ibadan.

[16]. Ikporukpo, C. O. and Filani, M. O (2000), "Transport coordination in Nigeria: trends and issues", The Nigerian Geographical Journal, New Series 3 and $429-42$.

[17]. Loeb, P.D., Clark, W.A. (2007), The determinants of truck accidents. Transportation Research Part E 43, $442-452$.

[18]. Mamman, A.B., (2005), Transport aspects of livestock marketing at the Achida and Sokoto Kara markets. Being a contribution to 'Investigations on Building a Food Marketing Policy evidence Base in Nigeria'. The United kingdom Department for International Development, March 25, 2005.

[19]. Mbendi (2011), http://www.mbendi.com/indy/oilf/ogds/af/ng/P0005.htm\#7 (2011).

[20]. Morgan, G.A., Leech, N.L., Gloeckner, G.W., and Barrent, K.C. (2004), SPSS for Introductory Statistics: Use and Interpretation, second ed. Lawrence Erlbaum Associates. Mahwah, NJ.

[21]. Olagunju, K. (2011), "Articulated Lorries management in Nigeria: Road Safety Perspective", a paper presented at the Road Safety forum, organized by the International Road Safety Organisation; at Ladi Kwali Hall, Sheraton Hotel $\&$ towers, Abuja, $6^{\text {th }}$ May, 2011.

[22]. Oni, S.I., (2008), Development of inland ports in Niigeria. In: Oyesiku, O.O., Gdadamosi, K.T. (Eds.) Port Administration and Development in Nigeria, first ed. HEBN Publishers, pp. 89-99.

[23]. Oni, S.I., and Okanlawon, K. (2006), Nigeria's transport infrastructural development: an integral part of the national economic empowerment and development strategy (NEEDS). Journal of Social and Policy Issues 3(2). $7-13$.

[24]. Oni, S.I. (2000), Encouraging a multimodal transport system in Nigeria. In: Paper presented at a seminar titled "Towards a Competitive and Sustainable Shipper-Friendly Shipping Enironment". National Shipping Council, Apapa-Lagos, Nigeria.

[25]. OPEC (2003), Organisation of the Petroleum Exporting Countries, Annual Statistics Bulletins 2002.

[26]. OPEC (2006), "Organization of the Petroleum Exporting Countries Review", XXXI, 1, March 2006, pp 30.

[27]. Potter, A., and Lalwani, C. (2008), Investigating the impact of demand amplification on freight transport. Transportation Research Part E 44, $835-846$.

[28]. Savage, I., (1989), The economic underpinning of transportation safety control. Department of Economics, Northwestern University, Evanston, II, August (Mimeo).

[29]. TELL Nigeria, (2005), The Making of a Revolution, special forum, p. 11.

[30]. Ubogu, A.E, (2005), An economic case for intermodal freight transport in Nigeria. Zaria Geographer 16(1), 1-12.

[31]. Ubogu, A.E., Ariyo, J.A., and Mamman M. (2011), "Port-hinterland trucking constraints in Nigeria", Journal of Transport Geography 19, (1), Elsevier Ltd, pp. 106-114.

[32]. Wilson, M.C., (2007), The impact of transportation disruptions on supply chain performance. Transportation Research Part E 43, $295-320$.

[33]. World Bank (2007), Nigeria: competitiveness and growth, In: Poverty Reduction and Economic Management 3, Country Department 12, Africa Ref: a, vol. 2, Report no. 36483-NG. 